Litinfinite Journal

ISSN: 2582-0400 [Online]

CODEN: LITIBR

Vol-2, Issue-1 ( $2^{\text {nd }}$ July, 2020)

Page No: $30-38$

DOI: 10.47365/litinfinite.2.1.2020.30-38

Section: Article

\title{
Marianne Moore's "Pigeons:" A Gateway Poem to Unveiling Eating Disorders in Her Poetry
}

\author{
Jessica (Tyner) Mehta \\ Postgraduate Researcher, \\ University of Exeter \\ England, United Kingdom \\ Mail I.d.: jt587@exeter.ac.uk
}

\begin{abstract}
:
How do eating disorders inform and reveal themselves in works of poetry, such as Marianne Moore's "Pigeons?" Using archival research at The Rosenbach Museum in Philadelphia along with medical texts and theories of the 1930s - 40s, this paper considers one of Moore's lesser known, uncollected poems as a means of teasing out how eating disorders play a prevalent role in her oeuvre. Disorders and diseases such as depression, anxiety, and addiction have received plenty of attention as a lens to approaching a poet's work. However, eating disorders are largely left out of these types of analyses, mirroring the unfortunate fact that eating disorders today are the deadliest, most underdiagnosed, and under-insured of any mental disorder. Such an oversight is glaring, particularly considering how relevant food and hunger are as symbolism in poetry. Failing to incorporate the role(s) eating disorders may play in a likely anorectic's work (Moore's) leaves a gaping disparity in a poet's or poem's comprehensive literary analysis. This paper aims to play a role in filling this disparity by focusing on eating disorders as lens with Moore's work.
\end{abstract}

Keywords: Poetry, Marianne Moore, eating disorders, anorexia, mental health.

"There is nothing I dislike more than the exposé," Marianne Moore revealed in a 1958 article titled "I, too, dislike poetry" for The Christian Science Monitor (Moore, 7).Three years later in 1961, Donald Hall interviewed Moore and asked her when she started to see poetry as "world-shaking" (Moore, 4). Her first inclination was to protest "Never!" but it did not take much prodding for Hall to uncover the truth. "This sounds rather pathetic," she confessed."Bizarre as well-I think verse perhaps was for me the next best thing to [fiction] ... I think I was all too truthful."

Moore was in her seventies when she wrote "I, too, dislike poetry" and was interviewed by Hall. As is often the case, in her twilight years she had become increasingly transparent and forthcoming. It is more than truthfulness, but a personal truthfulness, that is at the heart of Moore's poetry throughout her life, which is explored in "Pigeons" (Moore, 61 ) in this paper. "Pigeons" serves as an early clue to myriad struggles Moore faced throughout her life, each intricately interconnected, including: eating disorders, sexuality, and gender identification. Each of these issues was staunchly shushed during her lifetime, but perhaps poetry allowed for a means of self-inspection and truthfulness. 
Moore was not what some critics have called "distant from her own contemporary concerns" (Bazin, 3). She did not craft her poetry through what has been called a "detached viewpoint" (Weinstein, 375). Her poems were not "bloodless," as others have claimed (Wasserstrom, 262). Moore was an ardent, self-proclaimed observer who went so far as to title her first authorized collection Observations (1924), wherein 18 of the collection's 55 poems included the personal "I," "me," or "my." She was inarguably an observer, but we must not forget that observations can begin internally before being projected into-and onto- our external world. Of course, observations are also dependent on where a person is situated.

One should examine Moore, her work, and her poetic drafts not from a strictly biographical stance, but rather by a method of uncovering. Sometimes it is the undercurrents of a poet's works and efforts that reveal their true nature below the surface. Elizabeth Gregory was correct when she claimed that, for years, "critics worked under the biased misimpression that Moore essentially had no personal story" (Gregory, 4). It is those personal stories puzzled inside her poems that will be pieced together in this paper, including the likelihood of Moore having suffered from an eating disorder (ED). This is a poet who intentionally designed her verse to veil. She created in her poetry vast shadows and cubbies where she could camouflage her true self in metaphor and allegory, only revealing her authenticity to those readers who delved deep between the lines-and, perhaps, resonated with what they found.

Moore was essentially two people. One is the drug-addled, hidden, inner self on an endless mission toward perfectionism through medications, supplements, and tonics. This is demonstrated in her own archiving of numerous health clippings and prescriptions that she saved until her death. (needs a parenthetical intro to the following pic)

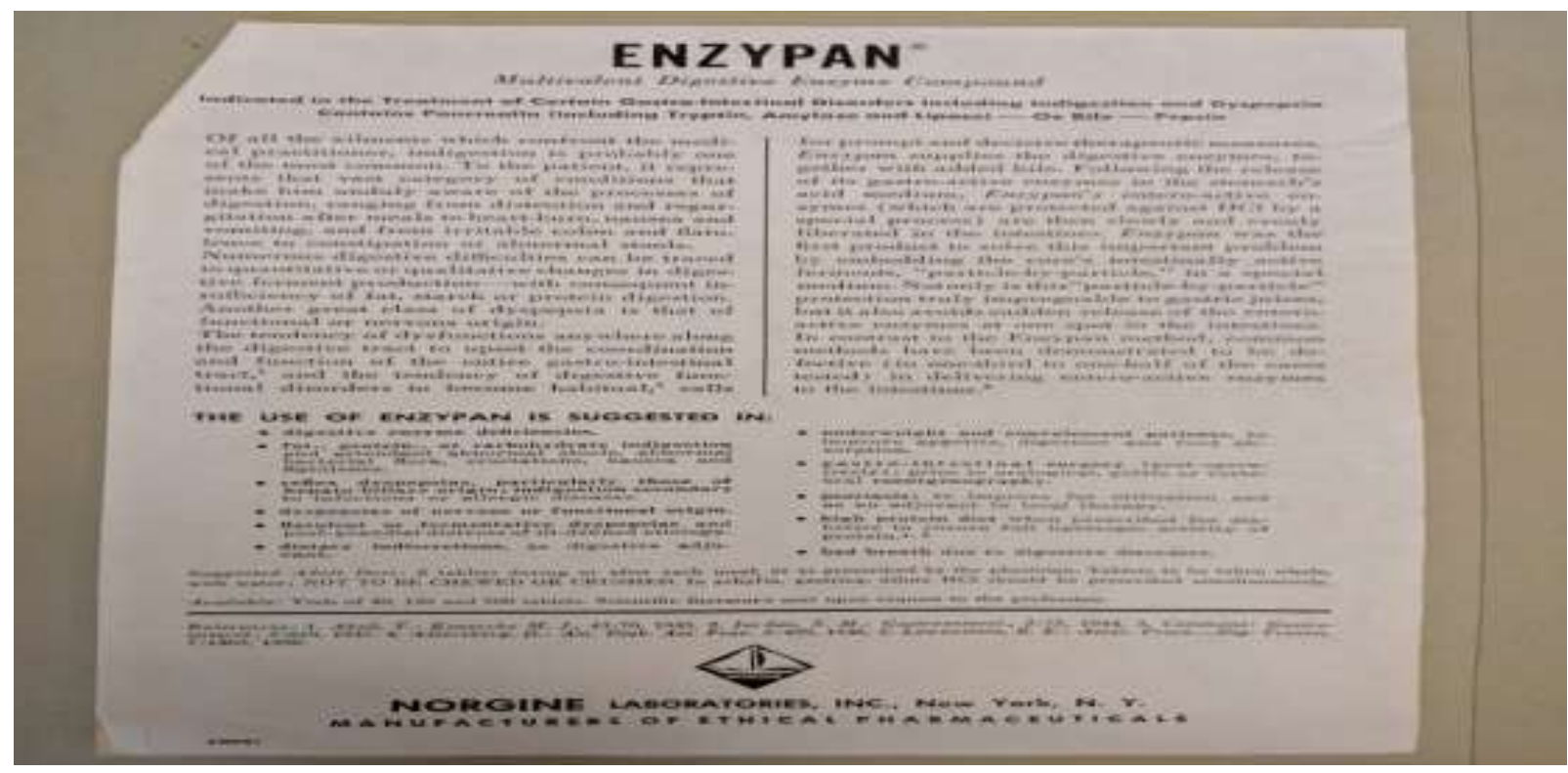

Image one: An example of one of many clippings Moore saved in her personal files relating to health and wellness. Dyspepsia is a common co-morbidity with anorexia, and was known as such during Moore's lifetime 
Her personal archiving was extensive, inching towards mania and obsession. Such characteristics can also be found in Moore's drafts and personal letters, particularly when discussing food. Mania and anorexia are established comorbidities, and this was known during Moore's lifetime. A 1904 article stressed the importance of recognizing signs of mental disorders that presented in physical manners. The case example was a patient who presented with anorexia and insomnia (insomnia being yet another anorectic co-morbidity) along with a "mean attack of acute mania" (Clouston, 207).

The details of Moore's food binges were exclusively shared with her brother, John Warner Moore, throughout her life, which suggests she feared reprimand if her mother, Mary Moore, knew of such gluttony. On 6 October 1940, she shared with her brother, "The shood was (much liquor), baked ham, string beans, potato balls in bread crumbs, celery \& Roquefort cheese, hot rolls, rye crisp, peace ice cream, layer cake \& coffee" ( Moore, 403). "Schood" was Moore's parlance for food, and perhaps a way of distancing herself (and her indulgences) from the food and act of eating.

These are examples of the personal side of Moore that are not obviously present in her poetry. The other half of Moore, the public poet, has been perceived by many as cold and distant-but look closer. Moore hid her revealing verse with a sturdy carapace, leaving a trail of hints and clues. There are certainly elements of dramatisation and problematizing in Moore's poetry, just as it is common for many people's journals $s$ to bloat with exaggeration. However, much like the ciphers attached to carrier pigeons during both World Wars, at the centre of Moore's poems are private revelations written in a poetic code.

Marianne Moore's own "Pigeons" was published by Poetry magazine but was never included in any of her collections - at least not in any version close to its Poetry incarnation. Although Moore's Selected Poems (1935) was published the same year as "Pigeons," Moore did not find it fitting for the book. Perhaps it simply did not work with the other poems, or maybe Moore thought that it needed more work-over a decade's worth of work. The poem actually does manifest itself again 14 years later as the more succinct and desperate "O to be a Dragon" (Moore, 22).

Understanding the full arc of this poem's evolution requires one to begin with the early, partial draft held at the Rosenbach Museum in Philadelphia, Pennsylvania. The notebook page with the poem's draft contains just eight lines that inspire "Pigeons," but even within these few lines her focus on placement, sequencing, and 
Litinfinite Journal

ISSN: 2582-0400 [Online]

CODEN: LITIBR

Vol-2, Issue-1 (2 $\left.{ }^{\text {nd }} J u l y, 2020\right)$

Page No: $30-38$

DOI: 10.47365/litinfinite.2.1.2020.30-38

Section: Article

omissions are pertinent (Moore VII:04:07 0035-recto). Below, consider the two different versions of "Pigeons." The first is the published version in Poetry followed by the draft of the poem held at the Rosenbach Museum:

Older than the ancient Greeks, than

Solomon, the pigeon family is a

ramifying one, a

banyan of banyans; to begin

with, bluish slate,

but with ability. Modesty cannot dull

the lustre of the pigeon

swift and sure, coming quickest and

straightest just after a storm. (Moore, 61)

before Solomon older than Solomon

than the ancient greeks the pigeon

family old \& honorable

proud famous

of race older than the greeks, than Solomon,

the homing the pigeon-modest bird one

family -modest one

$\mathrm{w} / \mathrm{a}$ pale seam of ending the 2 halves

(Moore VII:04:07, 0035-recto)

The draft starts with the conundrum of whether to begin the poem with "before" or "older." Moore ultimately opted for "older" in the poem's published form. She scratches out the first two words of the "Pigeons" draft ("before Solomon") and there are seven additional omissions in the sparse eight lines. (needs a parenthetical intro to the following pic)

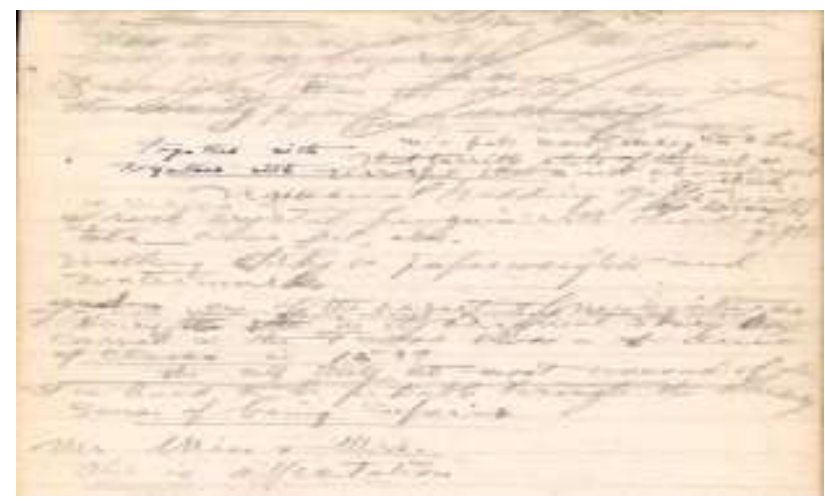

Image two: Moore's draft of "Pigeons," in The Marianne Moore Collection held at the Rosenbach Museum (Moore VII:04:07 0035-recto). 
CODEN: LITIBR

Vol-2, Issue-1 (2 $2^{\text {nd }}$ July, 2020)

Page No: $30-38$

DOI: 10.47365/litinfinite.2.1.2020.30-38

Section: Article

Deleting is a natural and common part of the editing process, but in looking at the choices of Moore's deleted words there are telling clues of her internal processes - both in terms of her writing and possible ED mechanisms. She herself claimed that "to delete is the instantaneous cure," which further marries the worlds of writing and health (Moore, 2). The deleted words and phrases in her draft of "Pigeons" include "before," "Solomon," "of race," "modest bird," and "modest one." Moore twice deleted the adjective "modest" in the draft, initially describing the pigeon as a "modest bird" and "modest one," but made the word a noun in the final draft with the line "Modesty cannot dull the lustre of the pigeon." Both modest and modesty imply moderation, limitation, a lack of excess or amount, and smallness, all of which mirror the aims of an ED. Omissions and deletions are also inherently a process and goal of those with an eating disorder (ED) such as anorexia nervosa (anorexia) and bulimia nervosa (bulimia).

Modesty can also be a means of deflecting sexual attention or an attempt to appear chaste. Moore's appearance remained exceptionally modest her entire life. Moore is not known to have taken any lovers, and there is evidence and debate surrounding her sexuality and possible lesbianism. Her seemingly strict observance of modesty also at least partially stemmed from the fact that her mother "subscribed to a Victorian understanding of childhood" and often urged her daughter (even while Moore was in college) to "be a little child again," which may be a root cause of Moore saying repeatedly as an adult that she "felt as old at thirteen as she ever would again" (Leavall, 45). Moore's commitment to her family, and especially her mother, remained steadfast throughout her life, perhaps to a damaging degree. Such dedication, the unique makeup of her family dynamics, and perhaps an underlying desire to claim independence can be found in the early draft of "Pigeons." Between the deleted word pairings "modest bird" and "modest one" are the words "one family." If Moore saw herself as the singular pigeon in her poem, doubly modest, she existed only within the construct of "one" single family made up of an overbearing mother, a brother, and (for much of Moore's upbringing) her mother's lover Mary Norcross. Moore attempts to delete the twinned modesty in the early draft of "Pigeons," but the term persisted in a new incarnation in the final version though in an entirely different context:

Modesty cannot dull

the lustre of the pigeon

swift and sure, coming quickest and

straightest just after a storm. (Moore, 120) 
CODEN: LITIBR

Vol-2, Issue-1 (2 $2^{\text {nd }}$ July, 2020)

Page No: $30-38$

DOI: 10.47365/litinfinite.2.1.2020.30-38

Section: Article

The final published version of "Pigeons" turned the "modest bird" into one sporting a rich lustre that not even the most fervent of modesty could dull.

Moore imbued the bird with power, control, and certainty, as well as the ability to move especially fast after a "storm," an event that can be seen as suggestive of two types of challenges. First, the pigeon can shine and is visible even within the most difficult and chaotic of situations. This is reflective of Moore's professional life despite what many would consider an oppressive, co-dependent family structure. Second, the storm could be the deepest pits of mental illness. Nothing equates so clearly to freedom as a bird -even one so often considered as lowly and common as a pigeon. The two types of storms Moore may be describing might also intersect. During the 1930s, medical experts were aware of the influence of family structure on anorectics. A 1931 pamphlet outlined the various views different doctors had of anorexia, and "while differing on some points, all [the doctors] lay stress on the ætiological importance of adverse external environment and agree that the symptoms concerned have the character of protest against authority" (Brierley, $63)$.

One critic has suggested that most of Moore's poems in the 1930s, including "Pigeons," are a "simple" illustration of reflection and mimesis coupled with "deadness" and a loss of power (Heuving, 155). The loss of power is certainly in keeping with how many anorectics perceive and design their lives, and of course "deadness" is the result of successful anorexia. In fact, feeling "dead" and "not human" were recurring descriptions of an anorexia case in 1942 (Moulton, 281). Heuving points to the lines in "Pigeons" that describe a "Mocker with one eye / destroyed" as evidence (Heuving, 155). No other direct lines from the poem are mentioned. Heuving states, that such lines while symbolic, are overwhelmed with"deadness," but she also takes the Mocker lines completely out of context. The specific pigeon Moore writes of in this line was Cher Ami, a working homing pigeon in World War I. Cheri Ami helped save 194 soldiers even after she - as the pigeon was a female (though Moore mis-gendered the bird) - lost not only an eye, but also a leg and was shot in the chest. Cher Ami survived her injuries and became an acclaimed war heroine that made numerous headlines. The complete stanza, ignored by Heuving, reads:

\section{The great}

lame ware hero Cher Ami, the

Lost Battalion's giant bird; and

Mocker with one eye

Destroyed, delivering his dispatch

To his superiors; (Moore, 120) 
It is clear upon inspection of Moore's complete description of Cher Ami that the poet admired the pigeon for her strength, courage, and fortitude. The pigeon in its entirety was far from destroyed. Moore even describes the pigeon as "giant," though female pigeons are smaller than males and Cher Ami was an average-sized bird for her species. However, it is curious that a poet as fastidious as Moore, particularly when it came to nature, mistook the pigeon for a male - if it was, in fact, a mistake. Maybe it was a type of Freudian slip or, as McCabe may have preferred, a Darwinian slip. McCabe argues that Moore's "Pigeons" is an important part of the "queer lineage" between the poet and Darwin (of whom Moore was an ardent reader), and that both Darwin and the pigeon motif were critical influences on Moore as a "modern queer poet" (McCabe, 555). Perhaps the mis-gendering was an instance of Moore again closely relating to the pigeon which was biologically female but was, in Moore's eyes, male. Moore adopted the male pronoun and a masculine nickname for herself (most often Rat) within her family at the onset of puberty and this remained so throughout her life (Gregory, 17). She and her brother called themselves "brothers" to one another and "uncles" to their mother, further exacerbating the family dysfunctions (Leavell, 49).

It is no surprise that Moore paid homage to the unremarkable pigeon. The poet, who spent most of her adult life in New York City, would have been familiar with the pervasive rats-with-wings that occupy every nook and cranny from the subways to the gardens and building ledges. Aligning herself with a pigeon, which she described in her poetry as an especially under-estimated and overlooked fowl, makes perfect sense. Pigeons are very location-specific in terms of their nests, and pigeon chicks (squabs) simply cannot survive without their parents. Compared to other birds, pigeon parents are very doting, and squabs are highly dependent, staying in their nest up to two weeks longer than most comparable birds. However, if Moore did indeed see herself as a pigeon in 1935, she re-imagined herself 24 years later as a different type of winged creature of a more fantastical, impressive variety. Moore's poem "O to Be a Dragon," also the title of her 1959 book, echoes the first two lines of "Pigeons" with a reference to Solomon and reads, in its entirety:

If I, like Solomon, ...

could have my wish-

my wish ... O to be a dragon, a symbol of the power of Heaven - of silkworm size or immense; at times invisible.

Felicitous phenomenon! (Moore, 9) 
The poem is the ardent hope of a 72-year-old single, now-motherless poet and not an evolution in her life. Even in her wildest fantasies and wishes, size mattered. Most people imagine dragons as huge behemoths, but Moore claimed that she would have been equally satisfied to be a dragon the size of a silkworm.

If Moore wrote herself metaphorically into her poems, first as a pigeon and then as a dragon, shrinking herself to the size of a silkworm, she aligned herself with the belief at the time that anorexia was a means to "prevent growing up" (Moulton, 293). During the 1940s, doctors studying EDs were also beginning to record the fantasies of their patients, with one case study revealing a woman who saw herself "like a little beast who wanted to eat up and tear up everything and everybody" (Lorand, 312). Such a description is fitting of any dragon, regardless of size.

\section{Works Cited}

i. $\quad$ "Anorexia Nervosa. A Discussion by Drs. W. Langdon Brown, F. G. Crookshank, J. C. Young, George Gordon and J. C. Bevan-Brown, 1931. Pp. 63. Price 2s. 6d." Journal of Mental Science 78.322 (1932): 725-725. Print.

ii. ---. "I, Too, Dislike Half-Poetry." College English, vol. 15, no. 2, 1953, p. 127. Crossref, doi: $10.2307 / 371495$.

iii. $\quad$---. Selected Poems. Main, Faber \& Faber, 2019.

iv. "Anorexia Nervosa. A Discussion by Drs. W. Langdon Brown, F. G. Crookshank, J. C. Young, George Gordon and J. C. Bevan-Brown, 1931. Pp. 63. Price 2s. 6d." Journal of Mental Science, vol. 78, no. 322, 1932, p. 725. Crossref, doi:10.1192/bjp.78.322.725.

v. "Anorexia Nervosa. A Discussion by Drs. W. Langdon Brown, F. G. Crookshank, J. C. Young, George Gordon and J. C. Bevan-Brown, 1931. Pp. 63. Price 2s. 6d." Journal of Mental Science, vol. 78, no. 322, 1932, p. 725. Crossref, doi:10.1192/bjp.78.322.725.

vi. "Anorexia Nervosa. A Discussion by Drs. W. Langdon Brown, F. G. Crookshank, J. C. Young, George Gordon and J. C. Bevan-Brown, 1931. Pp. 63. Price 2s. 6d." Journal of Mental Science, vol. 78, no. 322, 1932, p. 725. Crossref, doi:10.1192/bjp.78.322.725.

vii. Bazin, Victoria. Marianne Moore and the Cultures of Modernity. 1st ed., Routledge, 2010.

viii. Deese, Helen, and Margaret Holley. "The Poetry of Marianne Moore: A Study in Voice and Value." American Literature, vol. 61, no. 1, 1989, p. 140. Crossref, doi:10.2307/2926549.

ix. Gregory, Elizabeth. "Is Andy Warhol Marianne Moore? Celebrity, Celibacy and Subversion." Twenty-First Century Marianne Moore (2017): 237-251. Print.

x. Heuving, Jeanne. Omissions are Not Accidents: Gender in the Art of Marianne Moore. Detroit: Wayne State UP, 1992. Print.

xi. $\quad$ Leavell, Linda. Holding On Upside Down: The Life and Work of Marianne Moore. London: Faber \& Faber, 2013. Print.

xii. Lorand, Sandor. Anorexia Nervosa: Report of a Case. Evolution ofPsychosomatic Concepts: Anorexia Nervosa, a Paradigm. Edited by M. Kaufman and MarcelHeiman. International UP. 1964. 
Litinfinite Journal

ISSN: 2582-0400 [Online]

CODEN: LITIBR

Vol-2, Issue-1 ( $2^{\text {nd }}$ July, 2020)

Page No: $30-38$

DOI: 10.47365/litinfinite.2.1.2020.30-38

Section: Article

xiii. McCabe, Susan. "Survival of the Queerly Fit: Darwin, Marianne Moore, and Elizabeth Bishop." Twentieth-Century Literature 55.4 (2009): 547-571. Print.

xiv. Moore, Marianne (revised Dec 2015). The Marianne Moore Collection. Rosenbach of the Free Library ofPhiladelphia.

xv. Moore, Marianne, and Bonnie Costello. Selected Letters (Penguin Twentieth-Century Classics). First Paperback Edition, Penguin Classics, 1998.

xvi. Moore, Marianne. Idiosyncrasy and Technique. California: University of California Press, 1958. Print.

xvii. Moore, Marianne. Marianne Moore, The Art of Poetry. Donald Hall, Interviewer. TheParis Review, no. 26, pp. 4. 1961.

xviii. $\quad$ Moore, Marianne. O to Be a Dragon. 1st ed., The Viking Press, 1957.

xix. Moore, Marianne. New Collected Poems. New York: Farrar, Straus and Giroux, 2017. Print.

xx. Moore, Marianne. Observations: Poems. New York: Farrar, Straus and Giroux, 2016. Print.

xxi. Moulton, Ruth. A Psychosomatic Study of Anorexia Nervosa Including the Use of Vaginal Smears. Evolution ofPsychosomatic Concepts: Anorexia Nervosa, a Paradigm. Edited by M. Kaufman and Marcel Heiman.International UP. 1964.

xxii. Thaler, H., L. Benda, and E. Rissel. "Histologic Changes in Viral Hepatitis Studied by Liver Biopsy." Gastroenterology 33.2 (1957): 209-224. Print.

xxiii. Wasserstrom, William. Marianne Moore, 'The Dial,' and Kenneth Burke. WesternHumanities Review, vol. 16, no. 3, pp. 242-262. 1963.

xxiv. Weinstein, J. A. "Marianne Moore's Ecopoetic Architectonics." Interdisciplinary Studies in Literature and Environment, vol. 17, no. 2, 2010, pp. 373-88. Crossref, doi:10.1093/isle/isq035. 